\title{
Pollen morphology of Menispermaceae in the state of Bahia, Brazil ${ }^{1}$
}

\author{
Michella Del Rei Teixeira ${ }^{2,5}$, André Márcio Amorim ${ }^{2,3,4}$ and Francisco de Assis Ribeiro dos Santos
}

Submitted: 26 May, 2012. Accepted: 2 April, 2013

\begin{abstract}
There have been few palynological studies of the family Menispermaceae. Here, we analyzed the pollen grains of 12 species from seven genera of Menispermaceae occurring in the state of Bahia, Brazil: Abuta selloana Eichl.; Borismene japurensis (Mart.) Eichl.; Chondrodendron microphyllum (Eichl.) Moldenke; C. platyphyllum (A.St.-Hil.) Miers; Cissampelos andromorpha DC.; C. ovalifolia DC.; C. pareira L.; C. sympodialis Eichl.; Hyperbaena domingensis (DC.) Benth.; Odontocarya duckei Barneby; Sciadotenia campestris Barneby; and S. pubistaminea (K. Schum.) Diels. The pollen grains were acetolysed, measured, described, and illustrated using light and scanning electron microscopy. The pollen grains were found to be small, oblate spheroidal or prolate spheroidal, isopolar, and tricolpate or tricolporate; the exine was found to be reticulate. It was concluded that the various genera can be separated based on pollen characters. Within each of the genera, the species studied were stenopalynous. For five Menispermaceae species, pollen descriptions are presented here for the first time.
\end{abstract}

Key words: Palynology, taxonomy, stenopalynous

\section{Introduction}

The family Menispermaceae Juss. comprises 71 genera and approximately 500 species with largely pantropical distributions (e.g. Judd et al. 2007; Barneby \& White 2004; Jacques et al. 2007). Only a few species occur in temperate zones, between the eastern region of North America and eastern Asia (Jacques et al. 2007). Sixteen genera and 110 species occur in Brazil, with most of the native species occurring in the northern part of the country (Braga 2010).

Menispermaceae is widely known for its medicinal and toxic components. The roots and bark of many plants within this family (e.g., those within the genera Abuta, Chondrodendron, Cissampelos and Sciadotenia) contain alkaloids used as muscle relaxants in modern medicine or as poisons on the tips of arrows utilized by indigenous populations (Barneby 1975; Judd et al. 2007).

There have been few palynological studies of Menispermaceae. The revision published by Thanikaimoni (1968) presented a complete survey of the pollen morphology visible in light microscopy of representatives of the tribes of this family. Other authors have examined the pollen grains of the Menispermaceae and their relationships with the taxonomy of tribes such as Coscinieae, Fibraureae, Menispermeae, and Triclisieae (Ferguson 1975, 1978; Harley \& Ferguson 1982; Harley 1985).
More recent palynological studies of Menispermaceae have been published in pollen floras of specific geographical areas and have described the pollen grains of some species of the tribes Anomospermeae, Menispermeae, Tiliacoreae, and Tinosporeae. Salgado-Labouriau (1973) described the pollen grains of Cissampelos ovalifolia DC. as a contribution to the palynology of vegetation in the Brazilian cerrado (savanna); Palacios-Chávez et al. (1991) described the pollen grains of Cissampelos pareira L. from the Sian Ka'an Biosphere Reserve in Mexico; Roubik \& Moreno (1991) provided palynological data concerning four genera (Abuta Barrère ex Aubl., Chondrodendron Ruiz \& Pav., Cissampelos L., and Odontocarya Miers) represented by seven species in Panama; and Carreira \& Barth (2003) studied the pollen flora of vegetation growing on iron-rich soils known as cangas (hardpan soils) in Serra de Carajás, Brazil, describing the pollen grains of Cissampelos andromorpha DC.

The present study had the principal objective of analyzing the pollen grains of Menispermaceae species occurring in the state of Bahia, Brazil, in order to describe their morpho-palynological nature as well as to identify characters that could have diagnostic value at the genus or species level and contribute to taxonomic and related studies of this family.

\footnotetext{
${ }^{1}$ Based on the Master's dissertation of the first Author

${ }^{2}$ Universidade Estadual de Feira de Santana, Programa de Pós-Graduação em Botânica, Feira de Santana, Bahia, Brazil

${ }^{3}$ Universidade Estadual de Santa Cruz, Departamento de Ciências Biológicas, Ilhéus, Bahia, Brazil

${ }^{4}$ Centro de Pesquisas do Cacau, Comissão Executiva do Plano da Lavoura Cacaueira Herbário CEPEC, Ilhéus, Bahia, Brazil

${ }^{5}$ Author for correspondence: michelladelrei@yahoo.com.br
} 


\section{Materials and methods}

We examined the pollen grains of 12 species of seven genera of the family Menispermaceae occurring in the state of Bahia, Brazil. Although an earlier survey had registered 15 species in the state (Barneby 1996), three species-Abuta convexa (Vell.) Diels, Curarea crassa Barneby, and Orthomene schomburgkii (Miers) Barneby \& Krukoff-could not be included in the present study, either because of a lack of fertile material or because of a limited number of staminate inflorescences on the specimens in herbaria.

The study materials obtained from specimens deposited in the Herbarium of the Center for Cacao Research (code, CEPEC), Herbarium of the (Bahia) State University of Feira de Santana (code, HUEFS), and the Curitiba Municipal Botanical Museum (code, MBM) are listed as follows: Abuta selloana Eichl. - BRAZIL. Bahia: Valença, RPPN Fazenda Água Branca, P. Fiaschi et al. 2595, 30/X/ 2004 (CEPEC). Borismene japurensis (Mart.) Barneby. - BRAZIL. Bahia: Belmonte, Estação experimental Gregório Bondar, T.S. Santos 4345, 29/XI/1987 (CEPEC). Chondrodendron microphyllum (Eichl.) Moldenke - BRAZIL. Bahia: Arataca, Fazenda IESB - Serra das Lontras, M. Del-Rei et al. 44, 7/II/2009 (CEPEC); Bahia: Arataca, Serra Peito-de-Moça, W.W. Thomas et al. 14530, 18/I/2006 (CEPEC); Bahia: Santa Terezinha, Serra da Jibóia, M.L.C. Neves 39, 1/IV/2004 (HUEFS). Chondrodendron platiphyllum (A. St.-Hil.) Miers - BRAZIL. Bahia: Porto Seguro, BR 101, Montinho, T.S. Santos 1646, 15/V/1971 (CEPEC); Bahia: São Sebastião do Passé, Mata da Mariquita, M. Del-Rei et al. 61, 27/IX/2009 (HUEFS). Cissampelos andromorpha DC. - BRAZIL. Bahia: Ilhéus, área do CEPEC, J. L. Hage et al. 1408, 6/X/1981 (CEPEC); Bahia: Itacaré, $15,5 \mathrm{~km}$ da BR-101 via Itacaré, J.G. Jardim et al. 1136, 17/X/1997 (CEPEC); Bahia: Santa Cruz Cabrália, Reserva Biológica Pau-brasil, $A$. Eupunino 15, 1/X/1971 (CEPEC). Cissampelos ovalifolia DC. - BRAZIL. Bahia: Feira de Santana, 16/VI/2009, M. Del-Rei 58 (HUEFS); Bahia: Piatã, 16/X/1992,W. Ganev 1236 (HUEFS); Bahia: Barreiras, 2/XI/1987, L.P. Queiroz et al. 2095 (HUEFS). Cissampelos pareira L. BRAZIL. Bahia: Coribe, 8/VI/2007, M.M.M. Lopes et al. 1374 (CEPEC); Bahia: Feira de Santana, 16/VII/2009, $M$. Del-Rei 55 (HUEFS); Bahia: Feira de Santana, 9/XI/2004, S.F. Conceição et al. 86 (HUEFS). Cissampelos sympodialis Eichl. - BRAZIL. Bahia: Caldeirão Grande, 17/XI/1986, L.P. Queiroz 1166 (HUEFS); Bahia: Jacobina, 12/X/2007, J.L. Ferreira 124 (HUEFS); Bahia: Morro do Chapéu, 8/ VI/2001, E.R. Souza et al. 110 (HUEFS). Curarea crassa Barneby - BRAZIL. Bahia: Jaguaquara, 24/IV/2002, R.P. Oliveira et al. 786 (HUEFS); Bahia: Uruçuca, 12/ IV/1995, W.W. Thomas et al. 10900 (CEPEC). Hyperbaena domingensis (DC.) Benth. - BRAZIL. Bahia: sem localidade, BR-101, Vale do Rio Mucuri, 2/VI/1971, T.S. Santos 1538 (CEPEC); Bahia: Teixeira de Freitas,
11/X/1971, T.S. Santos et al. 2106 (CEPEC). Odontocarya duckei Barneby - BRAZIL. Bahia: Catolés, 4/II/2003, F. França et al. 4272 (HUEFS); Bahia: Rio de Contas, 3/XI/1988, R.M. Harley et al. 25898 (CEPEC). Sciadotenia campestris Barneby - BRAZIL. Bahia: Barreiras, 20/VIII/1986, G. Hatschbach \& J.M. Silva 50530 (holótipo MBM); Bahia: Correntina, 16/V/2000, G. Hatschbach et al. 71238 (MBM). Sciadotenia pubistaminea (K. Schum.) Diels - BRAZIL. Bahia: Encruzilhada, 17/VIII/2001, A.M. Carvalho et al. 6981 (CEPEC); Bahia: Vitória da Conquista, 22/III/1996, W.W. Thomas 11098 (CEPEC).

The pollen samples were prepared for light microscopy using the acetolysis method devised by Erdtman (1960). Slides were mounted using glycerin jelly. The measurements of polar and equatorial diameters were taken from 25 randomly pollen grains (whenever possible) in equatorial view; exine thicknesses were determined with 10 measurements. The polar/equatorial diameter ratio was used to define the shapes of the grains. The slides were subsequently incorporated into the palynological archives of the Plant Micromorphology Laboratory (LAMIV) at the State University of Feira de Santana.

For scanning electron microscopy (SEM) analyses, non-acetolysed pollen grains were scattered directly onto metallic supports and then coated with a thin layer of palladium gold (for approximately $3 \mathrm{~min}$ ) in a sputter-coater (SCD050; Bal-Tec/Leica Microsystems, Bannockburn, IL, USA).

The palynological terminology adopted follows Punt et al. (2007). For pollen size classes, we followed Erdtman (1952).

Photomicrographs were taken using an Olympus digital camera (Olympus, Tokyo, Brazil) mounted to a microscope (Axiostar Plus; Carl Zeiss, Oberkochen, Germany) with a $100 \times$ objective. The electron micrographs were taken using a scanning electron microscope (LEO 1430 VP; Carl Zeiss do Brasil, São Paulo, Brazil).

\section{Results}

The descriptions of pollen of Menispermaceae genera were based on species occurring in the state of Bahia, as listed below and detailed in Tab. 1 .

\section{Abuta Barrère ex Aubl.}

Fig. 1-3.

Pollen grains in monads, small, prolate spheroidal, isopolar, amb circular, tricolpate, polar area large; colpus approximately $2 / 3$ the length of the polar axis, apertural membrane ornamented with microspines; exine microreticulate to microechinate, irregular muri surface with sparse microspines (Fig. 1 and 3 ) that are visible only by SEM and difficult to measure, lumens poorly visible, heterogeneous; sexine the same thickness as nexine. Species examined: Abuta selloana Eichl. 
Table 1. Measurements of the pollen grains of Menispermaceae species in the state of Bahia, Brazil.

\begin{tabular}{|c|c|c|c|c|c|c|c|c|c|c|c|c|}
\hline \multirow[t]{2}{*}{ Species/Collector (Herbarium) } & \multicolumn{3}{|c|}{$\begin{array}{l}\text { Polar diameter } \\
(\mu \mathrm{m})\end{array}$} & \multicolumn{3}{|c|}{$\begin{array}{l}\text { Equatorial diameter } \\
\qquad(\mu \mathrm{m})\end{array}$} & \multirow[t]{2}{*}{ Shape } & \multirow[t]{2}{*}{$\mathrm{P} / \mathrm{E}$} & \multirow{2}{*}{$\begin{array}{l}\text { Exine } \\
\text { thickness } \\
(\mu \mathrm{m})\end{array}$} & \multirow{2}{*}{$\begin{array}{l}\text { Sexine/ } \\
\text { Nexine }\end{array}$} & \multirow{2}{*}{$\begin{array}{c}\text { AS } \\
(\mu \mathrm{m})\end{array}$} & \multirow[t]{2}{*}{ PAI } \\
\hline & Min. & $(\bar{x})$ & Max. & Min. & $(\bar{x})$ & Max. & & & & & & \\
\hline \multicolumn{13}{|l|}{ Abuta selloana (Velloso) Diels } \\
\hline P. Fiaschi et al. 2595 (CEPEC) & 13.0 & (13.5) & 14.0 & 12.0 & $(13.0)$ & 14.0 & prolate spheroidal & 1.04 & 1.5 & $\mathrm{~S}=\mathrm{N}$ & 7 & 0.54 \\
\hline \multicolumn{13}{|l|}{ Borismene japurensis (Mart.) Eichler } \\
\hline T.S. Santos et al. 4345 (CEPEC) & 13.0 & $(14.0)$ & 15.0 & 13.0 & (14.5) & 16.0 & oblate spheroidal & 0.97 & 1 & $\mathrm{~S}>\mathrm{N}$ & 5 & 0.34 \\
\hline \multicolumn{13}{|l|}{$\begin{array}{l}\text { Chondrodendron microphyllum (Eichler) } \\
\text { Moldenke }\end{array}$} \\
\hline M. Del-Rei et al. 44 (CEPEC) & 14.0 & $(15.0)$ & 16.0 & 14.0 & $(15.0)$ & 16.0 & spheroidal & 1 & 2 & $\mathrm{~S}>\mathrm{N}$ & 5 & 0.32 \\
\hline M.L.C. Neves et al. 39 (HUEFS) & 16.0 & $(17.0)$ & 18.0 & 15.0 & $(16.0)$ & 17.0 & prolate spheroidal & 1.06 & 2 & $\mathrm{~S}>\mathrm{N}$ & -- & -- \\
\hline W.W. Thomas et al. 14530 (CEPEC) & 15.0 & $(16.0)$ & 17.0 & 14.0 & $(15.0)$ & 16.0 & prolate spheroidal & 1.07 & 2 & $\mathrm{~S}>\mathrm{N}$ & -- & -- \\
\hline \multicolumn{13}{|c|}{ Chondrodendron platyphyllum (A. St.-Hil.) Miers } \\
\hline M. Del-Rei et al. 61 (HUEFS) & 14.0 & $(16.0)$ & 18.0 & 13.0 & $(14.5)$ & 16.0 & prolate spheroidal & 1.1 & 2 & $\mathrm{~S}>\mathrm{N}$ & 5 & 0.36 \\
\hline T.S. dos Santos et al. 1646 (CEPEC) & 14.0 & $(15.5)$ & 17.0 & 12.0 & (13.5) & 15.0 & prolate spheroidal & 1.15 & 1 & $\mathrm{~S}>\mathrm{N}$ & -- & -- \\
\hline \multicolumn{13}{|l|}{ Cissampelos andromorpha DC. } \\
\hline A. Eupunino 15 (CEPEC) & 15.0 & $(16.0)$ & 17.0 & 15.0 & $(16.0)$ & 17.0 & spheroidal & 1 & 2 & $\mathrm{~S}=\mathrm{N}$ & 6 & 0.38 \\
\hline J.G. Jardim et al. 1136 (CEPEC) & 15.0 & $(15.5)$ & 16.0 & 15.0 & $(16.0)$ & 17.0 & oblate spheroidal & 0.97 & 2 & $\mathrm{~S}=\mathrm{N}$ & -- & -- \\
\hline J.L. Hage et al. 1408 (CEPEC) & 15.0 & $(16.0)$ & 17.0 & 15.0 & $(16.0)$ & 17.0 & oblate spheroidal & 1 & 2 & $\mathrm{~S}=\mathrm{N}$ & -- & -- \\
\hline \multicolumn{13}{|l|}{ Cissampelos ovalifolia DC. } \\
\hline M. Del-Rei 58 (HUEFS) & 16.0 & $(18.0)$ & 20.0 & 18.0 & $(19.0)$ & 20.0 & oblate spheroidal & 0.95 & 2 & $\mathrm{~S}=\mathrm{N}$ & 7 & 0.39 \\
\hline W. Ganev et al. 1236 (HUEFS) & 16.0 & $(17.0)$ & 18.0 & 16.0 & $(17.0)$ & 18.0 & spheroidal & 1 & 2 & $S=N$ & -- & -- \\
\hline L.P. Queiroz et al. 2095 (HUEFS) & 16.0 & $(17.5)$ & 19.0 & 16.0 & $(18.0)$ & 20.0 & oblate spheroidal & 0.97 & 2 & $\mathrm{~S}=\mathrm{N}$ & -- & -- \\
\hline \multicolumn{13}{|l|}{ Cissampelos pareira $\mathrm{L}$. } \\
\hline M.M.M. Lopes 1374 (CEPEC) & 17.0 & $(18.0)$ & 19.0 & 19.0 & $(20.0)$ & 21.0 & oblate spheroidal & 0.9 & 2 & $\mathrm{~S}=\mathrm{N}$ & 5 & 0.25 \\
\hline M. Del-Rei 55 (HUEFS) & 14.0 & $(15.0)$ & 16.0 & 14.0 & (15.5) & 17.0 & oblate spheroidal & 0.97 & 2 & $\mathrm{~S}>\mathrm{N}$ & 5 & 0.31 \\
\hline S.F. Conceição et al. 86 (HUEFS) & 14.0 & $(15.5)$ & 17.0 & 15.0 & (16.5) & 18.0 & oblate spheroidal & 0.94 & 2 & $\mathrm{~S}>\mathrm{N}$ & -- & -- \\
\hline \multicolumn{13}{|l|}{ Cissampelos sympodialis Eichl. } \\
\hline J.L. Ferreira et al. 124 (HUEFS) & 12.0 & (13.5) & 15.0 & 12.0 & (13.5) & 15.0 & spheroidal & 1 & 2 & $\mathrm{~S}>\mathrm{N}$ & 6 & 0.41 \\
\hline E.R. Souza et al. 110 (HUEFS) & 14.0 & (15.5) & 17.0 & 14.0 & (15.5) & 17.0 & spheroidal & 1 & 2 & $\mathrm{~S}>\mathrm{N}$ & -- & -- \\
\hline L.P. Queiroz et al. 1166 (HUEFS) & 12.0 & $(14.0)$ & 16.0 & 12.0 & $(14.0)$ & 16.0 & spheroidal & 1 & 2 & $\mathrm{~S}>\mathrm{N}$ & -- & -- \\
\hline \multicolumn{13}{|l|}{ Hyperbaena domingensis (DC.) Benth. } \\
\hline T.S. Santos 1538 (CEPEC) & 14.0 & $(15.0)$ & 16.0 & 13.0 & (13.5) & 14.0 & prolate spheroidal & 1.11 & 1 & $\mathrm{~S}=\mathrm{N}$ & 6 & 0.41 \\
\hline T.S. Santos 2106 (CEPEC) & 13.0 & $(15.0)$ & 17.0 & 13.0 & $(14.5)$ & 16.0 & prolate spheroidal & 1.03 & 1 & $\mathrm{~S}=\mathrm{N}$ & -- & -- \\
\hline \multicolumn{13}{|l|}{ Odontocarya duckei Barneby } \\
\hline F. França et al. PCD 1296 (CEPEC) & 13.0 & $(14.0)$ & 15.0 & 13.0 & $(14.0)$ & 15.0 & spheroidal & 1 & 1 & $S>N$ & 2 & 0.15 \\
\hline R.M. Harley 25898 (HUEFS) & 13.0 & (14.5) & 16.0 & 12.0 & (13.5) & 15.0 & prolate spheroidal & 1.07 & 1 & $\mathrm{~S}>\mathrm{N}$ & & \\
\hline \multicolumn{13}{|l|}{ Sciadotenia campestris Barneby } \\
\hline G.M. Hatschbach et al. 50530 (MBM) & 12.0 & $(13.0)$ & 14.0 & 12.0 & $(13.0)$ & 14.0 & spheroidal & 1 & 1 & $S=N$ & 6 & 0.43 \\
\hline G.M. Hatschbach et al. 71238 (MBM) & 12.0 & $(14.0)$ & 16.0 & 13.0 & $(14.5)$ & 16.0 & oblate spheroidal & 0.97 & 2 & $\mathrm{~S}=\mathrm{N}$ & -- & -- \\
\hline \multicolumn{13}{|c|}{ Sciadotenia pubistaminea (K. Schum.) Diels } \\
\hline W.W. Thomas et al. 11098 (CEPEC) & 13.0 & $(14.0)$ & 15.0 & 12.0 & (13.0) & 14.0 & prolate spheroidal & 1.08 & 1 & $S=N$ & 7 & 0.5 \\
\hline A.M. Carvalho et al. 6981 (CEPEC) & 14.0 & $(15.0)$ & 16.0 & 13.0 & (14.5) & 16.0 & prolate spheroidal & 1.03 & 1 & $\mathrm{~S}=\mathrm{N}$ & -- & -- \\
\hline
\end{tabular}

Min. - minimum; $\bar{x}$ - arithmetic mean; Max. - maximum; P/E - polar/equatorial (diameter) ratio; AS - apocolpium side; PAI - polar area index; CEPEC - Herbarium of the Center for Cacao Research; HUEFS - Herbarium of the (Bahia) State University of Feira de Santana; MBM - Curitiba Municipal Botanical Museum. 


\section{Borismene Barneby}

Fig. 4-6.

Pollen grains in monads, small, oblate spheroidal, isopolar, amb circular, tricolporate, polar area small; ectoaperture approximately 2/3-3/4 the length of the polar axis, aperture membrane strongly granulate (Fig. 6), sometimes covering the circular endoaperture, making it difficult to observe; exine microreticulate, muri surface smooth, lumen small, heterogeneous, smaller near the apertures; sexine thicker than nexine. Species examined: Borismene japurensis (Mart.) Eichler.

\section{Chondrodendron Ruiz \& Pav.}

Fig. 7-13

Pollen grains in monads, small, spheroidal to prolate spheroidal in C. microphyllum and prolate spheroidal in C. platyphyllum, isopolar, amb subcircular, tricolporate, polar area small; ectoapertures approximately $2 / 3$ the length of the polar axis, narrow; endoapertures lolongate and difficult to see; exine microreticulate, muri surface irregular, with transversal constrictions (small folds) on the surface and scabrae that are difficult to see (Fig. 10), lumen small, polygonal, heterogeneous; sexine thicker than nexine. Species examined: C. microphyllum (Eichl.) Moldenke (Fig. 7-9) and C. platyphyllum (A. St.-Hil.) Miers (Fig. 10-13).

\section{Cissampelos L.}

Fig. 14-25

Pollen grains in monads, small, oblate spheroidal in $C$. pareira, oblate spheroidal to spheroidal in C. andromorpha and C. ovalifolia, spheroidal in C. sympodialis, isopolar, amb subcircular, tricolporate, polar area small; ectoapertures approximately $2 / 3-3 / 4$ the length of the polar axis; opercula narrow and long over the ectoapertures (Fig. 18 and 23), smaller in C. ovalifolia than in the other species; endoapertures lalongate and difficult to see; exine reticulate, muri surface smooth, lumen large, heterogeneous; sexine twice as thick as nexine. Species examined: C. andromorpha
DC.(Fig. 14-16), C. ovalifolia DC. (Fig. 16-17), C. pareira L. (Fig. 18-22), and C. sympodialis Eichl. (Fig. 23-25).

\section{Hyperbaena Miers ex Benth.}

Fig. 26-28

Pollen grains in monads, small, prolate-spheroidal, isopolar, amb sub-circular, tricolporate, polar area small; ectoaperture approximately $1 / 2-2 / 3$ the length of the polar axis; endoaperture circular; exine with cerebroid reticulate ornamentation (Fig. 26), muri thick and sinuous, surface smooth, lumens very small to large, heterogeneous; sexine the same thickness as nexine. Species examined: Hyperbaena domingensis (DC.) Benth.

\section{Odontocarya Miers}

Fig. 29-31

Pollen grains in monads, small, spheroidal to prolate spheroidal, isopolar, amb circular to subcircular, tricolporate, polar area very small; ectoaperture more than $3 / 4$ the length of the polar axis, sometimes fused at both poles (syncolporate, Fig. 29); opercula narrow and long over the ectoapertures (Fig. 29 and 31); endoaperture lolongate, diffuse, and difficult to see. Exine reticulate, with thin and slightly sinuous muri but with variable thicknesses, surface undulate, lumens heterogeneous; sexine twice as thick as nexine. Species examined: Odontocarya duckei Barneby.

\section{Sciadotenia Miers.}

Fig. 32-35

Pollen grains in monads, small, spheroidal in S. campestris and prolate spheroidal in S. pubistaminea, isopolar, amb circular, tricolpate, polar area small; colpi approximately 2/3-3/4 the length of the polar axis; exine microreticulate, with thick and sinuous walls (Fig. 33), muri surface smooth, lumen of variable sizes, heterogeneous; sexine twice as thick as nexine. Species examined: S. campestris Barneby (Fig. 32-34) and S. pubistaminea (K.Schum.) Diels (Fig. 35).

Pollen key for separating the genera of Menispermaceae occurring in the state of Bahia:

1. Pollen grains operculate

2. Pollen grains $\geq 15 \mu \mathrm{m}$, exine thickness $2 \mu \mathrm{m}$ 4. Cissampelos

2. Pollen grains $<15 \mu \mathrm{m}$, exine thickness $1 \mu \mathrm{m}$ 6. Odontocarya

1'. Pollen grains not operculate

3. Pollen grains colpate

4. Exine with microspines 1. Abuta

4. Exine without microspines 7. Sciadotenia

3. Pollen grains colporate

5. Muri with transversal constrictions 3. Chondrodendron

5. Muri without transversal constrictions, smooth

6. Exine with cerebroid reticulate ornamentation 5. Hyperbaena

6. Exine with microreticulate ornamentation. 2. Borismene 

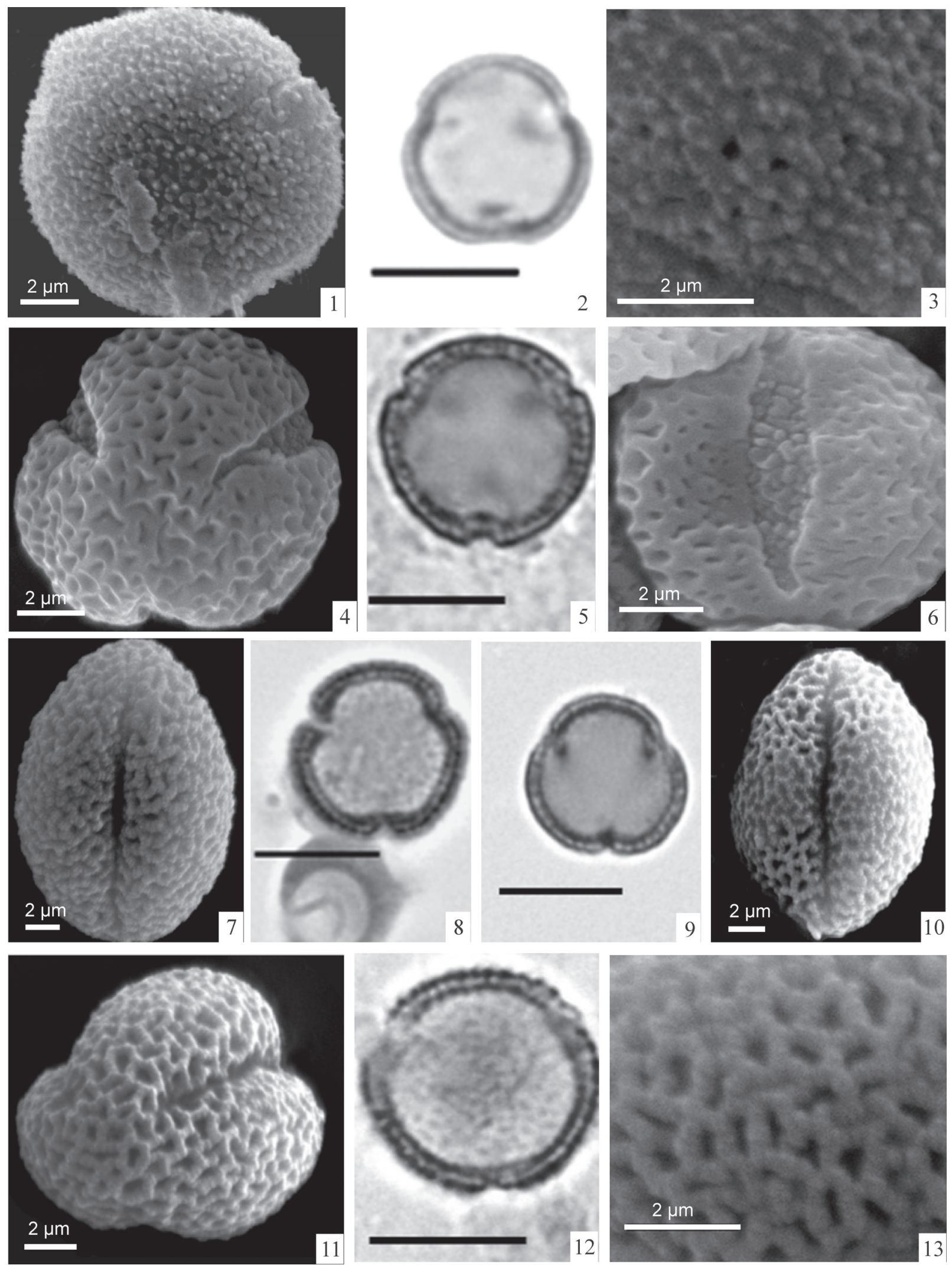

Figures 1-13. Pollen grains of Menispermaceae in the state of Bahia, Brazil, under light microscopy and scanning electron microscopy (SEM). Fig. 1-3. Abuta selloana Eichl.: 1. Polar view (SEM); 2. Polar view; 3. Equatorial view, colpus and surface (SEM) -Fig. 4-6. Borismene japurensis (Mart.) Eichl.: 4. Polar view (SEM); 5. Polar view; 6. Equatorial view (SEM). 7-9. Chondrodendron microphyllum (Eichl.) Moldenke: 7. Equatorial view, colpus and surface (SEM); 8, 9. Polar view-Fig. 10-13. Chondrodendron platyphyllum (A. St.-Hil.) Miers: 10. Equatorial view (SEM); 11. Polar view (SEM); 12. Polar view; 13. Polar view, surface. (Scale bar $=10 \mu \mathrm{m}$, Fig. 2, 5, 8, 9, 12). 

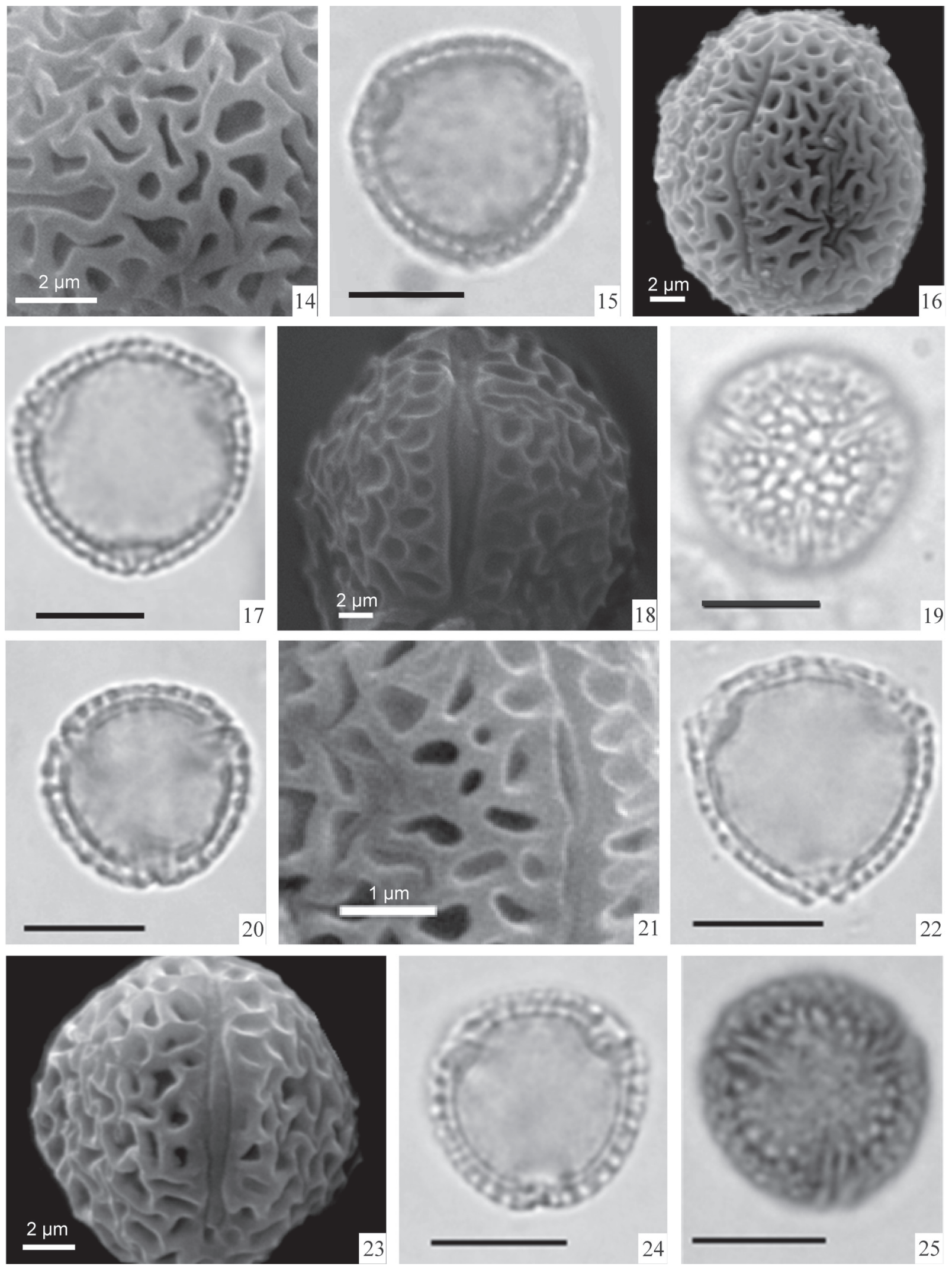

Figures 14-25. Pollen grains of Menispermaceae in the state of Bahia, Brazil, under light microscopy and scanning electron microscopy (SEM). Fig. 14 15. Cissampelos andromorpha DC.: 14. Polar view, surface (SEM); 15. Polar view-Fig. 16, 17. Cissampelos ovalifolia DC.: 16. Equatorial view, colpus and surface (SEM); 17. Polar view-Fig. 18-22. Cissampelos pareira L.: 18. Equatorial view, colpus and surface (SEM); 19. Polar view, surface; 20. Polar view; 21. Equatorial view, colpus and surface (SEM); 22. Polar view-Fig. 23-25. Cissampelos sympodialis Eichl.: 23. Equatorial view, colpus (SEM); 24. Polar view; 25. Polar view, surface. (Scale bar $=10 \mu \mathrm{m}$, Fig. 15, 17, 19, 20, 22-24). 

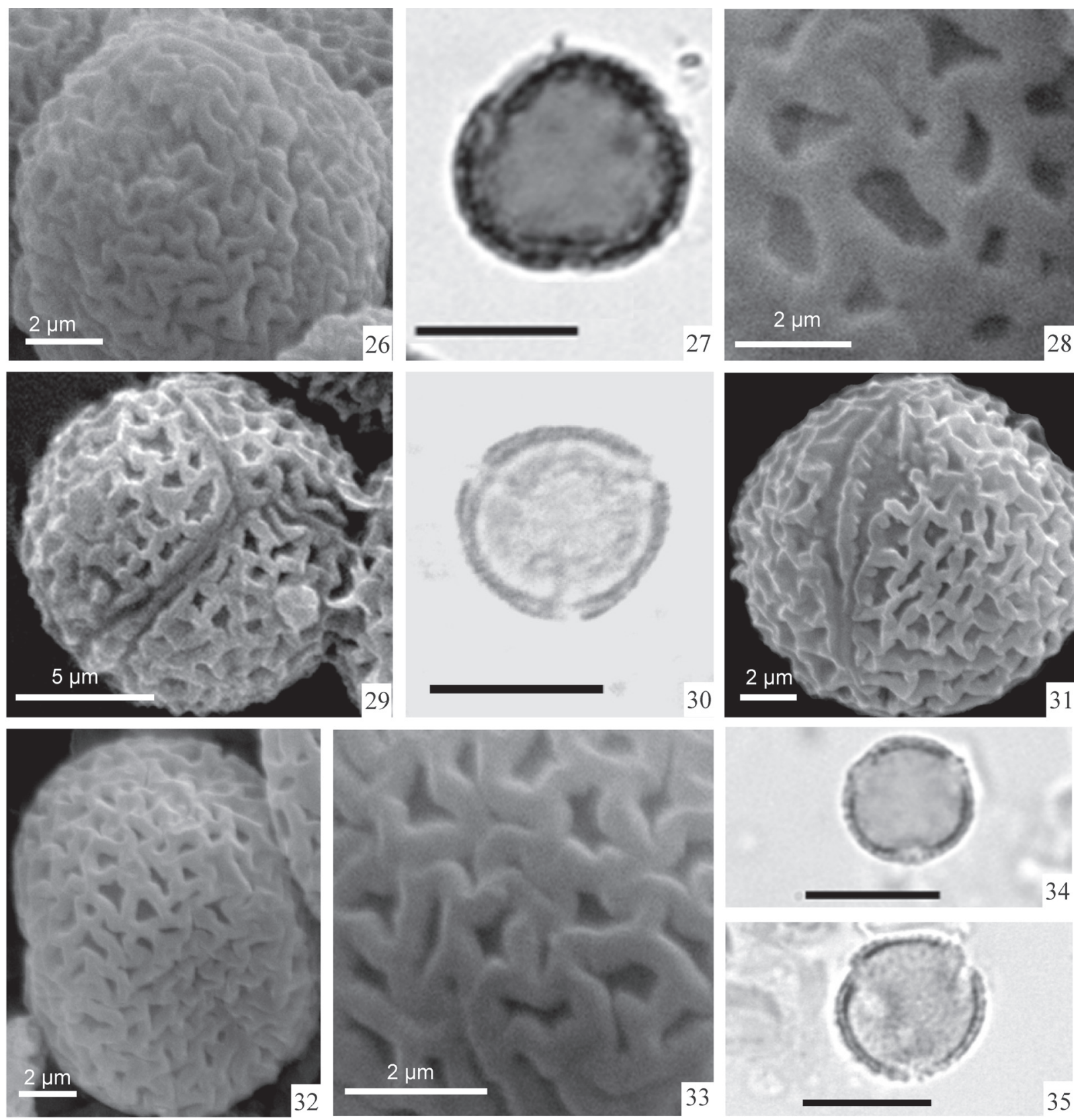

Figures 26-35. Pollen grains de Menispermaceae in the state of Bahia, Brazil, under light microscopy and scanning electron microscopy (SEM). Fig. 26-28. Hyperbaena domingensis (DC.) Benth.: 26. Equatorial view (SEM); 27. Polar view; 28. Equatorial view, surface (SEM) - Fig. 29-31. Odontocarya duckei Barneby: 29. Polar view (SEM). 30. Polar view. 31. Equatorial view, colpus and surface (SEM) - Fig. 32-34. Sciadotenia campestris Barneby: 32 . Equatorial view (SEM); 33. Equatorial view, surface (SEM); 34. Polar view-Fig. 35. Sciadotenia pubistaminea (K. Schum.) Diels: Polar view. (Scale bar = 10 $\mu$ m, Fig. 27, 30, 34, 35).

\section{Discussion}

The seven genera of Menispermaceae occurring in the state of Bahia were studied and the characteristics of the 13 species analyzed corroborated the findings of classical studies (Erdtman 1952; Thanikaimoni 1968; Ferguson 1975). For five species, the present study represents the first time that their pollen grains have been described: Abuta selloana, Chondrodendron microphyllum, Cissampelos sympodialis, Odontocarya duckei, and Sciadotenia campestris.
The pollen grains of species within the same genus were found to be stenopalynous, showing only small morphological differences. The genera, however, are more palynologically distinct, and it is possible to identify them according to their pollen characters.

All of the pollen grains studied are dispersed in monads and are isopolar, varying in shape from oblate to prolate-spheroidal. The Cissampelos species analyzed here vary from oblate spheroidal to spheroidal. The Chondrodendron species have pollen grains that are predominantly prolate 
spheroidal, except for one specimen of C. microphyllum that presents spheroidal pollen grains. The pollen grains of the Sciadotenia species vary from oblate-spheroidal (S. campestris) to prolate-spheroidal (S. pubistaminea). All of the species have small pollen grains, varying from $13 \mu \mathrm{m}$ in Sciadotenia campestris (G.M. Hatschbach et al. 50530) to 20 $\mu \mathrm{m}$ in Cissampelos pareira (M.M.M. Lopes 1374).

The pollen grains of the genera Abuta and Sciadotenia are predominantly colpate, whereas those of Borismene, Chondrodendron, Cissampelos, Hyperbaena, and Odontocarya are colporate. Colpi lengths vary from $2 / 3$ to $3 / 4$ of the length of the polar axis. The pollen grains of Odontocarya duckei have longer colpi, which were often fused at the poles (syncolporate). Most of the colporate pollen grains, mainly those with opercula, had endoapertures that were quite difficult to see.

Most of the species have microreticulate sexine with smooth surfaces; transversal constrictions on the muri surface were observed only in Chondrodendron species. Microspines were observed on the surface of the pollen grains of Abuta selloana.

The proportions of sexine and nexine thicknesses in the pollen wall varied among the genera studied, although the sexine are generally observed to be thicker than the nexine. Nexine and sexine thicknesses are similar only among the genera Abuta, Hyperbaena, and Sciadotenia.

The prolate spheroidal shape attributed to the pollen grains of Cissampelos ovalifolia by Salgado-Labouriau (1973) diverged from the results of the present study, although interpretations of pollen shapes are often influenced by the laboratory techniques used.

For many years, a tricolpate aperture was thought to represent a primitive characteristic in this family, with tricolpate, triporate and inaperturate pollen grains being considered derived characters (Thanikaimoni 1986). However, within the phylogenetic context of the molecular data presented by Ortiz et al. (2007) and Hoot et al. (2009), the pollen grains were found to be extremely homoplastic-the basal condition of the family is probably triaperturate-tricolpate or triporate (Hoot et al. 2009).

The small size of the sample examined here prevented us from establishing an evolutionary hypothesis related to the pollen characters of the Menispermaceae. However, our results, contextualized within those of the molecular phylogenetic studies conducted by Ortiz et al. (2007) and Hoot et al. (2009), indicate that the apomorphic condition of the colporate pollen type with a circular endoaperture (shared by Borismene and Hyperbaena) and the presence of an operculum (shared by Odontocarya and Cissampelos) are homoplastic aspects and have arisen several times in the evolutionary history of this family.

Based on data presented here, we can conclude that species within each genus of Menispermaceae demonstrate significant morphological homogeneity in terms of their pollen characters, principally in terms of the number, type, and ornamentation of their apertures. However, major differences were noted between the genera in terms of characters such as aperture type, size, and exine ornamentation as observed under SEM.

Despite the similarity of the pollen grains (suggesting close relationships) among the species of the various genera analyzed here, these taxa are otherwise quite distinct in terms of their vegetative and reproductive morphologies. Although the analysis of pollen morphology can be useful in taxonomic studies of this group, it should be considered only as an additional tool for species classification.

\section{Acknowledgments}

The authors would like to thank the staff of the Plant Micromorphology Laboratory at the Universidade Estadual de Feira de Santana (UEFS, [Bahia] State University of Feira de Santana) especially Dr. Paulino Pereira Oliveira, for providing access to the laboratory facilities; the staff of the UEFS Electron Microscopy Laboratory, especially the technician Gisele Rocha for her help in preparing the electron micrographs; and the staff of the Animal Histology Laboratory at the Universidade Estadual de Santa Cruz (UESC, Santa Cruz State University [of Bahia]), especially Prof. Guisla Boehs for her help in preparing the light photomicrographs. This study received financial support in the form of research grants from the Brazilian Coordenação de Aperfeiçoamento de Pessoal de Nivel Superior (CAPES, Office for the Advancement of Higher Education; master's scholarship grant to MDRT) and Conselho Nacional de Desenvolvimento Científico e Tecnológico (CNPq, National Council for Scientific and Technological Development; productivity grants to AMA and FARS).

\section{References}

Barneby, R.C. 1975. Menispermaceae. Pp. 3-40. In: Reitz R. (Ed.). Flora Ilustrada Catarinense. Itajaí, Herbário Barbosa Rodrigues.

Barneby, R.C. 1996. Tiding of Menispermaceae from interior French Guiana and from the Brazilian State of Bahia. Brittonia 48(1): 20-25.

Barneby, R.C.; White, P. 2004. Menispermaceae (Moonseed Family). Pp. 247-249. In: Smith, N.; Mori, S.A.; Henderson, A.; Stevenson, D.W. \& Heald, S.V. (Eds). Flowering Plants of the Neotropics. Princeton, Princeton University Press.

Braga, J.M.A. 2010. Menispermaceae. In: Forzza, R.C.; Leitman, P.M.; Costa, A.F.; Carvalho Jr., A.A.; Peixoto, A.L.; Walter, B.M.T.; Bicudo, C.; Zappi, D.; Costa, D.P.; Lleras, E.; Martinelli, G.; Lima, H.C.; Prado, J.; Stehmann, J.R.; Baumgratz, J.F.A.; Pirani, J.R.; Sylvestre, L.; Maia, L.C.; Lohmann, L.G.; Queiroz, L.P.; Silveira, M.; Coelho, M.N.; Mamede, M.C.; Bastos, M.N.C.; Morim, M.N.C.; Barbosa, M.R.; Menezes, M.; Hopkins, M.; Secco, R.; Cavalcanti, T.B. \& Souza, V.C. (Orgs). Lista de Espécies da Flora do Brasil. http://floradobrasil.jbrj.gov.br/2010/ FB000163. Acesso em 22/09/2010.

Carreira, L.M.M. \& Barth, O.M. 2003. Atlas de pólen da vegetação de canga da Serra de Carajás. Belém, Museu Paraense Emílio Goeldi.

Erdtman, G. 1952. Pollen Morphology and Plant Taxonomy Angiosperms. Stockholm, Almquist \& Wiksell.

Erdtman, G. 1960. The acetolysis method. A revised description. Svensk Botanisk Tidskrft 39: 561-564. 
Ferguson, I.K. 1975. Pollen Morphology of the Tribe Triclisieae of the Menispermaceae in relation to its taxonomy. Kew Bulletin 30(1): 49-75.

Ferguson, I.K. 1978. Pollen Morphology of the Tribe Coscinieae of the Menispermaceae in relation to its taxonomy. Kew Bulletin 32(2): 339-346.

Harley, M.M. 1985. Pollen morphology and Taxonomy of the Tribe Fibraureae (Menispermaceae). Kew Bulletin 40(3): 553-565.

Harley, M.M. \& Ferguson, I.K. 1982. Pollen Morphology and Taxonomy of the Tribe Menispermeae (Menispermaceae). Kew Bulletin 37(3): 353-366.

Hoot, S.B.; Zautke, H.; Harris, D.J.; Crane P.R. \& Neves S.S. 2009. Phylogenetic Patterns in Menispermaceae Based on Multiple Chloroplast Sequence Data. Systematic Botany 34(1): 44-56.

Jacques, F.M.B.; Gallut, C.; Vignes-Lebbe, V. \& Bagils, R.Z. 2007. Resolving phylogenetic reconstruction in Menispermaceae (Ranunculales) using fossils and a novel statistical test. Taxon 56(2): 379-392.

Judd, W.S.; Campbell, C.S.; Kellogg, E.A.; Stevens, P.F. \& Donoghue, M.J. 2007. Plant systematics: a phylogenetic approach. 2nd ed. Sunderland, Sinauer Associates.
Ortiz, R.; Kellogg, E.A. \& van der Werff, H. 2007. Molecular phylogeny of the moonseed family (Menispermaceae): implications for morphological diversification. American Journal of Botany 94: 1425-1438.

Palacios-Chávez, R.; Ludlow-Wiechers, B. \& Villanueva, R.G. 1991. Flora palinológica de la Reserva de La Biósfera de Sian Ka’an, Quintana Roo, Mexico. Chetumal, Centro de Investigaciones de Quintana Roo. Punt, W.; Hoen, P.P.; Blackmore, S.; Nilsson, S. \& Le Thomas, A. 2007. Glossary of pollen and spores terminology. Review of Paleobotany and Palynology 143: 1-81.

Roubik, D.W. \& Moreno P., J.E. 1991. Pollen and spores of Barro Colorado Island. Monographs in Systematic Botany 36: 1-270.

Salgado-Labouriau, M.L. 1973. Contribuição à palinologia dos cerrados. Rio de Janeiro, Academia Brasileria de Ciências.

Thanikaimoni, G. 1968. Morphologie des pollens des Menispermacées. Institut Français de Pondichéry. Travaux de la Section Scientifique et Technique 5: 1-56.

Thanikaimoni, G. 1986. Evolution of Menispermaceae. Canadian Journal of Botany 64: 3130-3133. 